\title{
Midterm experience with modified Cabrol procedure: Safe and durable for complex aortic root replacement
}

\author{
Bulat A. Ziganshin, MD, ${ }^{\mathrm{a}, \mathrm{b}}$ Francois E. Williams, ${ }^{\mathrm{c}}$ Maryann Tranquilli, RN, ${ }^{\mathrm{a}}$ and John A. Elefteriades, MD ${ }^{\mathrm{a}}$
}

Objective: To evaluate the early and late outcomes of the modified Cabrol technique as a method of coronary reimplantation during complex composite graft replacement of the ascending aorta.

\begin{abstract}
Methods: Between 1995 and 2012, 348 patients (mean age, $56 \pm 14$ years; 283 males and 65 females) underwent composite graft replacement of the ascending aorta, 40 of whom (mean age, $60 \pm 12$ years; 35 males and 5 females) had one or both coronary ostia reimplanted using a modified Cabrol technique with an 8- to 10-mm Dacron interposition graft. The mean clinical and radiologic (computed tomographic scan) postoperative follow-up was 39 months (range, 1-171 months), via our aortic database, patient interviews, and Social Security Death Index.

Results: Cabrol reimplantation was necessitated by reoperations with anatomically fixed coronary ostia $(\mathrm{n}=16$, $40 \%)$, severely displaced coronary arteries $(\mathrm{n}=15,37.5 \%)$, button calcification $(\mathrm{n}=4,10 \%)$, coronary anomalies $(\mathrm{n}=3,7.5 \%)$, and coronary aneurysm $(\mathrm{n}=2,5 \%)$. Of the operations, $20 \%$ (8 patients) were urgent interventions. Early mortality was $3(7.5 \%)$ of 40 , none related to the Dacron interposition graft. Total late mortality was $16.2 \%$, also not related to the coronary graft. Actuarial survivals were $0.88 \pm 0.05,0.79 \pm 0.07$, and $0.73 \pm 0.08$ at 1,3 , and 6 years, respectively. Radiologic follow-up was available for $31(83.8 \%)$ of the surviving patients and revealed that the interposition graft was widely patent in all.
\end{abstract}

Conclusions: The modified Cabrol technique using a Dacron interposition graft showed good survival rates and excellent durability over time, confirmed radiographically. These data confirm that it is appropriate to use the Cabrol technique when technical complexity prevents bringing coronary buttons to the main aortic graft. (J Thorac Cardiovasc Surg 2014;147:1233-9)

Current surgical therapy for patients with aortic root aneurysms or dissections of the ascending aorta involves either composite graft replacement of the aorta or a valvesparing aortic replacement. ${ }^{1}$ Either approach requires meticulous reimplantation of the ostia of coronary arteries into the newly implanted aortic graft. Over the years, there has been debate regarding the optimal strategy for reimplanting the coronary arteries into the graft, ${ }^{2}$ since the first report of Wheat et $\mathrm{al}^{3}$ of a successful replacement of the ascending aorta and aortic valve. The procedure originally described by Bentall and De Bono ${ }^{4}$ in 1968 (later known as the "classic Bentall procedure") involved reimplantation of the coronary ostia into the aortic graft. In 1981, Carbol described an alternative technique for restoring blood flow to the coronary arteries using a "moustache-shaped" interposition graft. ${ }^{5}$ This procedure later became known as the "classic Cabrol technique." Concerns over patency plagued

\footnotetext{
From the Aortic Institute, ${ }^{\text {a }}$ Yale University, New Haven, Conn; Department of Surgical Diseases 2, ${ }^{\text {b }}$ Kazan State Medical University, Kazan, Russia; and Xavier University of Louisiana, ${ }^{\mathrm{c}}$ New Orleans, La.

Disclosures: Authors have nothing to disclose with regard to commercial support.

Received for publication Jan 30, 2013; revisions received Feb 25, 2013; accepted for publication March 14, 2013; available ahead of print April 29, 2013.

Address for reprints: John A. Elefteriades, MD, Aortic Institute, Boardman 204, 330

Cedar St, New Haven, CT 06510 (E-mail: john.elefteriades@yale.edu).

$0022-5223 / \$ 36.00$

Copyright (c) 2014 by The American Association for Thoracic Surgery

http://dx.doi.org/10.1016/j.jtcvs.2013.03.027
}

this procedure. More recently, a modification of the original Bentall technique, namely the "button technique" of Kouchoukos et al, ${ }^{6}$ which requires mobilization of the coronary ostia and formation of coronary "buttons," has gained popularity and is considered the gold standard for aortic root replacement operations.

Although initially reported with excellent results by Cabrol himself, ${ }^{7}$ the Cabrol technique over the years became nearly obsolete because of reports of stenosis, thrombosis, and occlusion of the interposition graft. $^{2,8-12}$ In 2003, Gelsomino et $\mathrm{al}^{2}$ reported a nonnegligible incidence of early and long-term complications and recommended against using this procedure. The classic Cabrol reimplantation technique uses one relatively long interposition graft, one end of which is anastomosed to the right and the other end to the left coronary ostium, with a further side-to-side anastomosis with the aortic graft. ${ }^{5}$ However, in recent years, many modifications of the Cabrol technique have been described, most of which are summarized in an excellent report by Kourliouros et al. ${ }^{13}$ One of the Cabrol modifications that has gained popularity is the technique of using 2 short separate interposition grafts, which are directly implanted into the aortic graft. The first such experience was described by Piehler and Pluth, ${ }^{14}$ who used a short Gore-Tex graft for reimplanting the left coronary artery, while the right coronary artery was reimplanted directly into the aortic graft with the inclusion technique. However, there is controversy 


\section{Abbreviations and Acronyms \\ $\mathrm{CT}=$ computed tomography \\ DHCA $=$ deep hypothermic circulatory arrest}

as to whether this technique should be referred to as the modification of the Cabrol or the Bentall procedure. Mills et $\mathrm{al}^{15}$ and Kourliouros et $\mathrm{al}^{13}$ consider this to be a modification of the Cabrol technique. At the same time, Hirasawa et $\mathrm{al}^{16}$ and Maureira et $\mathrm{al}^{17}$ tend to name it a modification of the Bentall procedure. It seems that relative length of the interposition grafts is the decisive criterion, with longer grafts being referred to as Cabrol modifications and shorter ones as Bentall modifications. For simplicity, in this report, all coronary reimplantation techniques with a separate interposition graft will be referred to as "modified Cabrol technique."

At our institution, we use the classic Cabrol technique and its modifications on rare and complex occasions and believe that it is a useful technique in the arsenal of a cardiothoracic surgeon. We find this option helpful when the contemporary button technique cannot be used, usually because of fixation of the coronary ostia as the result of reoperation or inflammation. Thus, the aim of this study is to evaluate the early and long-term outcomes associated with the Cabrol technique, with specific attention to the fate of the coronary interposition graft on radiologic follow-up.

\section{METHODS \\ Patient Profile}

During a 17-year period between January 1995 and October 2012, 348 patients (mean age, $56 \pm 14$ years; 283 males and 65 females) underwent composite graft replacement of the ascending aorta at Yale-New Haven Hospital (New Haven, Conn). Forty (11.5\%) of these patients had one or both coronary ostia reimplanted using a modified Cabrol technique with an 8- to 10-mm Dacron interposition graft. In one case, a saphenous vein graft was used instead. The remaining 308 patients underwent a conventional button reimplantation technique. The frequency of composite graft replacement procedures increased over the years, as did the frequency of using the Cabrol technique (1995-2005, 7; 2006-2012, 33). This report will focus on the 40 Cabrol patients.

The detailed preoperative characteristics of the patients operated on by the modified Cabrol technique are presented in Table 1, and are compared with the preoperative characteristics of the patients operated on by the conventional coronary button reimplantation technique. The Cabrol patient group had a significantly higher percentage of redo cardiac procedures and emergency interventions. The prevalence of diabetes was significantly greater among the Cabrol patients, whereas the prevalence of hypertension and hyperlipidemia was higher in the conventional button technique group.

Sixteen of the Cabrol patients ( $40 \%$ ) had undergone at least one previous open-heart procedure, of which 11 were related to the aorta or aortic valve, 3 were coronary artery bypass operations, 1 was a mitral valve replacement, and 1 was a closure of a ventricular septal defect. One patient had 3 previous cardiac operations for congenital defects. The indications for surgery in patients who were operated on using the Cabrol technique were the following: annuloaortic ectasia $(n=24)$, chronic dissection $(\mathrm{n}=8)$, acute dissection $(\mathrm{n}=5)$, and reoperation for aortic stenosis
( $n=3 ; 2$ of these were cases of aortic valve stenosis of previously implanted homografts, and 1 was a case of isolated aortic stenosis with a normal-sized aorta).

\section{Operative Technique}

All operations were performed through a standard median sternotomy with the use of cardiopulmonary bypass. Operative data are shown in Table 2 . The femoral artery was used in $34(85 \%)$ cases and was the preferred arterial cannulation site. Our approach and technique of femoral cannulation was reported previously. ${ }^{18}$ Other cannulation sites included the aortic arch ( 3 patients), the axillary artery ( 2 patients), and the innominate artery (1 patient). Venous return was via the right atrial appendage in 37 patients and the femoral vein in 3 patients. Patients were cooled systemically to $24^{\circ} \mathrm{C}$ to $26^{\circ} \mathrm{C}$, unless we anticipated the need for circulatory arrest, in which case cooling to a level of deep hypothermia was performed $\left(18^{\circ} \mathrm{C}\right.$ $19^{\circ} \mathrm{C}$ ). Straight deep hypothermic circulatory arrest (DHCA) was used as the sole means of cerebral protection in this group of patients, according to the technique described earlier. ${ }^{19,20}$ No additional cerebral perfusion adjuncts (antegrade or retrograde cerebral perfusion) were used. DHCA was necessitated in cases of total or partial replacement of the aortic arch and in complex reoperative cases when an open distal anastomosis of the ascending aorta was safer to perform. Myocardial protection was achieved by infusing crystalloid cardioplegia through the coronary sinus in a retrograde manner.

Replacement of the aortic valve, aortic root, and ascending aorta was performed using a valved conduit. In 25 patients $(62.5 \%)$, a prefabricated St Jude mechanical valved conduit was used (St Jude Medical, St Paul, Minn). Bioprosthetic aortic valves were used in 13 patients $(32.5 \%)$. In 10 patients, the tissue valve conduit was created in the operating room by hand sewing a Carpentier-Edwards bioprosthetic aortic valve (Carpentier-Edwards, Irvine, Calif) into a Hemashield graft (Boston Scientific, Natick, Mass). In 2 patients, a Medtronic Freestyle Aortic Root Bioprosthesis (Medtronic, Minneapolis, Minn) was used. One patient required an isolated aortic valve replacement, which was performed using a Carpentier-Edwards tissue valve. In 2 cases, we were able to preserve the prosthetic aortic valves, which were implanted during previous cardiac procedures.

In cases when direct reimplantation of one or both coronary ostia into the neoaorta was not feasible, reimplantation using the modified Cabrol technique was implemented. The indications for using the Cabrol reimplantation technique were the following: reoperations with anatomically fixed coronary ostia $(n=16,40 \%)$, severely displaced coronary arteries $(\mathrm{n}=15,37.5 \%)$, severe coronary button calcification $(\mathrm{n}=4,10 \%)$, coronary anomalies $(n=3,7.5 \%)$, and ostial coronary aneurysm $(n=2,5 \%)$.

We used 3 different modifications of the classic Cabrol reimplantation technique, which were all slightly different from the originally proposed method:

1. Both right and left coronary ostia reimplanted using one long interposition graft $(\mathrm{n}=2)$.

2. Both right and left coronary ostia reimplanted using 2 short separate interposition grafts $(n=3)$.

3. Either right or left coronary ostium reimplanted using a separate interposition graft $(\mathrm{n}=35)$.

The first modification is similar to the classic Cabrol technique, except that the interposition graft is anastomosed with coronary buttons cut out of the wall of the aorta and the remaining diseased aorta extirpated. In the original technique, the interposition graft is anastomosed with the coronary orifices using the inclusion technique. In this modification, the interposition graft was anastomosed side to side to the aortic graft. In modifications 2 and 3 , the interposition graft was also anastomosed with coronary buttons, but was attached end to side to the neoaorta. In all cases, 8- to 10-mm tubular Dacron grafts were used according to the policy and practice of our institution to use the same size of the interposition graft, as was reported by Cabrol et $\mathrm{al}^{5,7}$ in the original reports. In 27 cases $(67.5 \%)$, the Dacron graft was anastomosed with the right coronary ostium; in 8 cases $(20 \%)$ with the 
TABLE 1. Comparison of preoperative characteristics of patients operated on by the modified Cabrol coronary reimplantation technique and by the conventional "button" reimplantation technique

\begin{tabular}{|c|c|c|c|c|c|}
\hline \multirow[b]{2}{*}{ Variable } & \multicolumn{2}{|c|}{ Modified Cabrol technique group } & \multicolumn{2}{|c|}{ Conventional "button" technique group } & \multirow[b]{2}{*}{$P$ valu } \\
\hline & Value & $\%$ & Value & $\%$ & \\
\hline Total no. of patients & 40 & 100 & 308 & 100 & \\
\hline Male to female ratio & $35: 5$ & $87.5: 12.2$ & $248: 60$ & $80.5: 19.5$ & \\
\hline \multicolumn{6}{|l|}{ Age, y } \\
\hline Mean \pm SD & $60 \pm 12$ & & $56 \pm 14$ & & .08 \\
\hline Range & $31-82$ & & $17-97$ & & \\
\hline Emergency operations & 8 & 20 & 12 & 3.9 & $<.001 *$ \\
\hline Previous cardiac surgery & 16 & 40 & 14 & 4.5 & $<.001 *$ \\
\hline \multicolumn{6}{|l|}{ Comorbidities/risk factors } \\
\hline Aortic regurgitation & 24 & 60 & 196 & 63.6 & .65 \\
\hline Hypertension & 17 & 42.5 & 203 & 65.9 & $<.01 *$ \\
\hline Concomitant aneurysm of the aortic arch & 16 & 40 & 88 & 28.6 & .14 \\
\hline Bicuspid aortic valve & 8 & 20 & 80 & 26 & .41 \\
\hline Positive family history of aortic diseases & 7 & 17.5 & 93 & 30.5 & .09 \\
\hline History of cardiac arrhythmias & 7 & 17.5 & 35 & 11.4 & .19 \\
\hline Diabetes & 5 & 12.5 & 12 & 3.9 & $<.05^{*}$ \\
\hline COPD & 3 & 7.5 & 29 & 9.4 & .48 \\
\hline Hyperlipidemia & 2 & 5 & 110 & 35.7 & $<.001 *$ \\
\hline Marfan syndrome & 2 & 5 & 23 & 7.5 & .43 \\
\hline Renal failure & 1 & 2.5 & 9 & 2.9 & .68 \\
\hline Stroke & 1 & 2.5 & 4 & 1.3 & .46 \\
\hline \multicolumn{6}{|l|}{ Maximal aortic diameter, $\mathrm{cm}$} \\
\hline Mean \pm SD & $5.68 \pm 1.5$ & & $5.63 \pm 0.9$ & & .25 \\
\hline Range & $3.8-10.8$ & & $3.7-11.0$ & & \\
\hline
\end{tabular}

$C O P D$, Chronic obstructive pulmonary disease; $S D$, standard deviation. *Significant difference.

left coronary ostium; and in 5 cases $(12.5 \%)$ with both. In one patient, a saphenous vein graft was used to reimplant the right coronary artery, whereas the left coronary artery was reimplanted with a Dacron graft.

Two patients had a single coronary ostium, with both coronary arteries originating from the left coronary ostium in the midposterior position of the

\section{TABLE 2. Operative data}

\begin{tabular}{lc}
\hline \multicolumn{1}{c}{ Variable } & Value (\%) \\
\hline Cardiopulmonary bypass time, min* & $168.5 \pm 29.8$ \\
Aortic cross-clamp time, min* & $122.3 \pm 44.3$ \\
Prosthetic valve type & \\
Mechanical & $25(62.5)$ \\
Biological & $13(32.5)$ \\
Previously implanted prosthetic valve preserved & $2(5)$ \\
Graft diameter, mm* & $24.8 \pm 3.3$ \\
Cabrol graft diameter, mm* & $8.7 \pm 2.3$ \\
Associated cardiac procedures & \\
Partial aortic arch replacement (deep hemiarch) & $11(27.5)$ \\
Total aortic arch replacement, stage 1 elephant trunk & $5(12.5)$ \\
CABG & $2(5)$ \\
VSD closure & $1(2.5)$ \\
Ligation of patent ductus arteriosus & $1(2.5)$ \\
Ligation of left atrial appendage & $1(2.5)$ \\
Cerebral protection & \\
Straight DHCA & $21(52.5)$ \\
DHCA time, min* & $29.9 \pm 7.5$ \\
\hline
\end{tabular}

$C A B G$, Coronary artery bypass grafting; $V S D$, ventricular septal defect; $D H C A$, deep hypothermic circulatory arrest. *Data are given as mean \pm SD. aorta. In one case, a large accessory branch originated from the same ostium as the right coronary artery. The Cabrol technique in these cases was needed to prevent kinking of either of the 2 coronary branches. In the case with 2 vessels originating from the right coronary artery ostium, a short Dacron graft came off the main graft at a right angle, traveling to the single button carrying both coronary arteries.

The patient who required isolated aortic valve replacement previously had a 4 -vessel coronary artery bypass surgery with all 4 proximal anastomoses ( 3 saphenous vein grafts and 1 internal mammary artery graft) constructed low at the level of the proximal ascending aorta. In addition, the right coronary artery ostium was enlarged and completely prevented access to the aortic root. In this setting, the decision was made to remove the right coronary ostium as a button, which permitted good access to the aortic root that was sufficient for a valve replacement procedure. However, reanastomosing the button to the aorta would have been dangerous, with potential traction on the displaced coronary ostium; thus, reimplantation was achieved through a modified Cabrol technique.

All operations were performed by one cardiothoracic surgeon (J.A.E.).

\section{Postoperative Follow-up}

Postoperative clinical and radiologic (computed tomography [CT] scan) follow-up was achieved via the Aortic Database of the Aortic Institute at Yale-New Haven Hospital and through clinical visits, patient interviews, and the Social Security Death Index. We have institutional review board approval to observe aortic patients clinically over time. Radiologic follow-up was focused on determining the long-term patency of the Cabrol interposition graft to the coronary ostia (Figure 1). The mean clinical and radiologic follow-up was 39 months (range, 1-171 months) after the surgical intervention. CT scans were reviewed and evaluated by an experienced radiologist. 


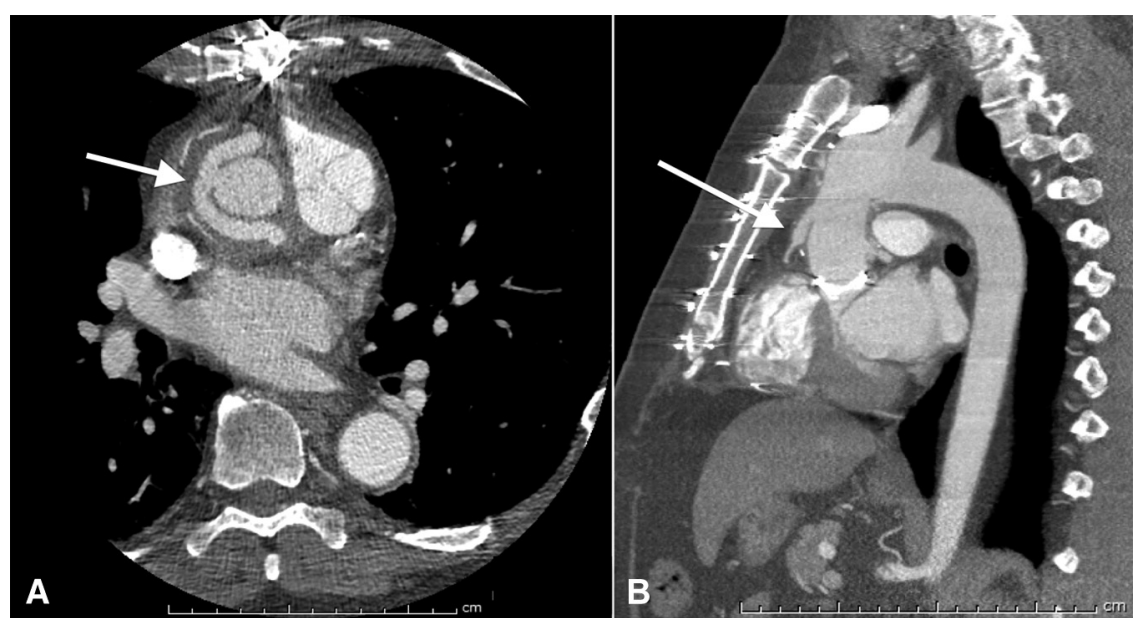

FIGURE 1. A, A 36-month postoperative follow-up contrast enhanced computed tomography (CT) scan (axial plane) showing $100 \%$ patency of the Dacron interposition graft (white arrow) between the left and right coronary ostia. B, A 35-month postoperative follow-up contrast enhanced CT scan (sagittal plane) showing $100 \%$ patency of the Dacron interposition graft (white arrow) to the right coronary ostium.

The causes of early and late deaths were determined for all patients either from the patients' medical records (in-hospital records or ambulatory records of the referring physicians) or by death certificates.

\section{Statistical Analysis}

The results of descriptive statistics are presented as mean \pm SD. The 2-tailed, unpaired $t$ test was used to evaluate the difference between the mean age of patients and maximal aortic diameter. The Pearson $\chi^{2}$ test and Fisher exact test were used to compare proportions in the preoperative characteristics between patients in the modified Cabrol technique and conventional button reimplantation technique groups. Statistical significance was defined as $P<.05$. The Kaplan-Meier actuarial method was used to analyze the mortality and estimate long-term survival.

\section{RESULTS \\ Early Morbidity}

Six patients $(15 \%)$ required reexploration for bleeding, and $16(40 \%)$ developed atrial fibrillation, which later resolved in $12(30 \%)$ of patients. Other early postoperative complications included respiratory failure $(\mathrm{n}=1)$, pneumonia $(\mathrm{n}=1)$, and cellulitis in a saphenous vein site $(\mathrm{n}=1)$. No patients developed transient or permanent neurologic complications.

\section{Early Mortality}

Three patients $(7.5 \%)$ died in the first 30 days after surgical intervention (Table 3). All 3 patients had previous cardiac operations and severe adhesions. One patient presented with endocarditis of a previously implanted homograft. One patient had a chronic aortic dissection. Of the 3 patients, 2 had concomitant aneurysm of the aortic arch, which required deep hemiarch replacement under DHCA. Two of these patients required reexploration for bleeding. One patient had an autopsy performed (patient 3 in Table 3), which showed full patency of the Cabrol interposition graft.
Although it is difficult to determine causes of death with absolute security for the other 2 early deaths (and for the late death of patient 4 from Table 4), all these patients were under direct care by our team (including cardiac reexplorations) and were not prospectively or retrospectively deemed related to the Cabrol grafts. Even in detailed reexamination of all the clinical data in retrospect for this report, there is no evidence to suggest Cabrol-related death.

\section{Late Mortality}

Survival data were available for all $(100 \%)$ of the patients. Postoperative follow-up revealed $6(16.2 \%)$ late deaths, the causes of which are listed in Table 4.

One patient died of left ventricular failure (late death 4), which was a preexisting condition in the patient and developed years before the aortic operation. The severity of left ventricular failure required us to implant a left ventricular assist device at the time of the aortic root procedure. Two months later, the patient was admitted for a second procedure aimed at explanting the left ventricular assist device and implanting a different one. During this complex procedure, the patient expired.

For the remaining late deaths, discrete, noncardiac causes were established, which were clearly identified based on the information from the death certificates (late death patients 1 and 2) and the medical information available from the primary care providers (late death patients 3 and 6). Late death patients 4 and 5 have information about the causes of their deaths available through our own medical records and through our Aortic Institute's database. None of the late deaths were related to the Cabrol interposition graft.

The actuarial survivals were $0.88 \pm 0.05,0.79 \pm 0.07$, and $0.73 \pm 0.08$ at 1,3 , and 6 years, respectively (Figure 2). Freedom from reoperation on the ascending aorta was $100 \%$. 
TABLE 3. Early deaths

\begin{tabular}{|c|c|c|c|c|}
\hline Patient no. & Age, $y$ & Reoperation? (S/P) & Other preoperative conditions & Cause of death \\
\hline 1 & 75 & Yes (type A dissection) & Severe AI, advanced CHF, stroke & $\begin{array}{l}\text { Hypoxic ischemic encephalopathy } \\
\text { secondary to bleeding }\end{array}$ \\
\hline 2 & 82 & Yes (AVR, CABG) & $\begin{array}{l}\text { Aortic arch aneurysm, severe } \mathrm{CAD} \text {, occluded } \\
\text { vein graft to CMA, TI, chronic atrial fibrillation, } \\
\text { carotid artery stenosis }\end{array}$ & Ventricular arrhythmia (preexisting) \\
\hline 3 & 50 & $\begin{array}{l}\text { Yes (homograft replacement } \\
\text { of aortic valve and aortic root) }\end{array}$ & $\begin{array}{l}\text { Severe stenosis of bioprosthetic aortic valve, } \\
\text { endocarditis }\end{array}$ & $\begin{array}{l}\text { Hypovolemic shock due to extreme } \\
\text { polyuria }\end{array}$ \\
\hline
\end{tabular}

$S / P$, Status post; $A I$, aortic insufficiency; $C H F$, congestive heart failure; $A V R$, aortic valve replacement; $C A B G$, coronary artery bypass grafting; $C A D$, coronary artery disease; $C M A$, circumflex marginal artery; $T I$, tricuspid insufficiency.

\section{Long-Term Dacron Interposition Graft Patency Evaluation}

Radiologic follow-up was available for $31(83.8 \%)$ of the 37 patients who survived the aortic procedure: 27 survivors $(87.1 \%)$ and 4 patients with late deaths (late deaths 1-3 and 6 in Table 4). The mean clinical and radiologic (CT scan) postoperative follow-up was 39 months (range, 1-171 months). Among the Dacron grafts that were evaluated radiologically, $100 \%$ showed wide patency with no mural thrombus formation. No signs of stenosis or occlusion were detected.

However, the saphenous vein graft used in one patient was $85 \%$ stenosed and symptomatic 14 months after the operation. Attempts for percutaneous stent placement failed. The patient remains alive 48 months postoperatively, with the vein graft still stenosed to the same degree.

\section{DISCUSSION}

In this study, we have shown that the Cabrol graft procedure and its modifications can be safely used for complex aortic root replacement procedures, when the conventional button reimplantation technique is not feasible. Long-term patency of the Dacron interposition grafts is $100 \%$, radiographically confirmed.

TABLE 4. Causes of late deaths

\begin{tabular}{|c|c|c|c|c|}
\hline $\begin{array}{c}\text { Patient } \\
\text { no. }\end{array}$ & $\begin{array}{c}\text { Age at } \\
\text { death, } \\
y\end{array}$ & Reoperation* & Cause of death & $\begin{array}{c}\text { Postoperative } \\
\text { time at } \\
\text { which death } \\
\text { occurred, mo }\end{array}$ \\
\hline 1 & 58 & No & Stroke & 36 \\
\hline 2 & 70 & Yes & $\begin{array}{c}\text { Gastrointestinal } \\
\text { hemorrhage }\end{array}$ & 64 \\
\hline 3 & 80 & Yes & $\begin{array}{l}\text { Bleeding after AAA } \\
\text { repair }\end{array}$ & 33 \\
\hline 4 & 57 & Yes & Left ventricular failure & 2 \\
\hline 5 & 46 & Yes & $\begin{array}{l}\text { MSSA bacteremia, } \\
\text { septic shock }\end{array}$ & 3 \\
\hline 6 & 54 & Yes & Brain tumor & 32 \\
\hline
\end{tabular}

Cabrol developed this technique of coronary artery reimplantation to provide an alternative method to the Bentall technique, which would provide a reliable tension-free anastomosis of the coronary arteries with the new aortic graft and have less risk of developing suture-line pseudoaneurysms. $^{5,7}$ It also permits access to the coronary anastomoses sites for inspection for potential bleeding. Some early reports published in the 1990s actually showed benefits of the Cabrol technique over the Bentall technique and even the button technique. ${ }^{8,21,22}$ Svensson et $\mathrm{al}^{8}$ noted that dissecting coronary buttons, especially the left main, takes a considerable amount of time compared with the time needed to anastomose the interposition graft. However, over time and with growing experience, the button reimplantation technique became the gold standard for performing valve-sparing or composite graft replacements of the aortic root. ${ }^{13}$

The occurrence of interposition graft stenosis, thrombosis, and occlusion requiring reoperation ${ }^{2,8-12,23}$ was one of the reasons for the Cabrol technique to be sidelined from routine use and reserved only for the most complex cases of aortic replacement, often redo procedures with displaced and calcified coronary ostia. Thus, over the years, only a few studies have been able to assess the

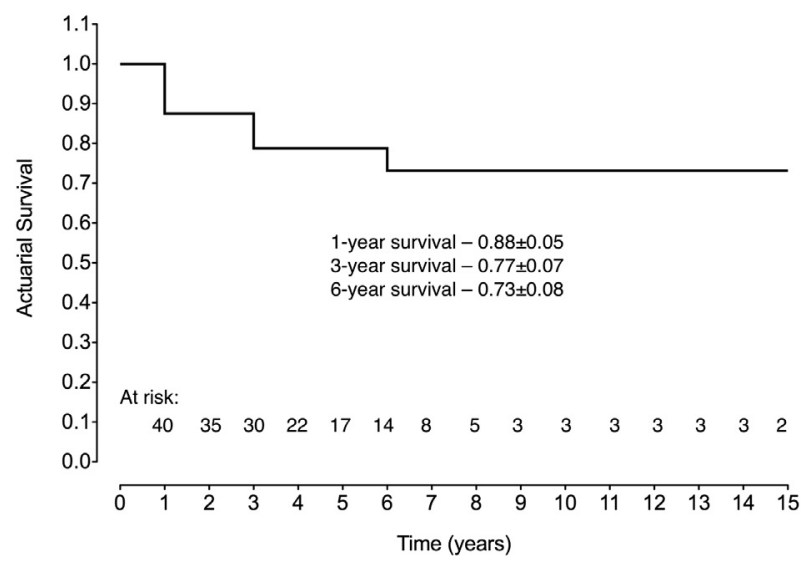

FIGURE 2. Actuarial survival after composite graft replacement of the ascending aorta using the Cabrol technique for coronary artery reimplantation. 
results of the Cabrol procedure (most relevant studies are listed in Table 5), with few patients. Often, these studies show inferiority of the Cabrol technique in terms of early mortality and long-term survival; however, this may be related to patient profile, because only the most complicated cases are treated with the Cabrol reimplantation technique. Likewise, in our study, the group of patients who underwent the modified Cabrol procedure was also a select group of complex patients, as detailed herein. Specifically, compared with the patients who underwent conventional composite grafting concurrently, the patients who required a Cabrol graft were more likely to undergo redo or emergency operations.

Nonetheless, our study shows good results in terms of mortality and morbidity.

Long-term patency of the interposition graft has been questioned. Several studies have shown the anastomosis with the ostium of the right coronary artery to be much more susceptible to kinking, postoperative stenosis, and occlusion (Table 5). ${ }^{8,9,23}$ A study of computational flow dynamics by Knight et $a l,{ }^{24}$ conducted on 7 patients who underwent the Cabrol procedure, showed a spiraling flow pattern with low flow into the right coronary artery, which could explain a higher incidence of complications involving the right limb of the interposition graft. Although problems with the right limb of the interposition graft could reflect certain specifics of the operative approach in each study, it is apparent that efforts must be taken to prevent such complications. In our experience, in most cases, we used short interposition grafts for each coronary artery, which may avoid disadvantages inherent in the original Cabrol moustache. We did not find problems related to either the right or the left Dacron grafts. None of the early or late deaths was attributed to the Cabrol graft. Postoperative CT scans showed $100 \%$ patency of all Dacron grafts. The high percentage of radiographic visualization of the Cabrol grafts in this study adds reassuringly to the confidence with which this procedure can be applied when needed clinically.

\section{Limitations of the Study}

This study is limited by relatively few patients, the heterogeneity of the study group, and the fact that the study is retrospective. It is also difficult to make direct comparisons to studies that evaluated the classic Cabrol procedure, because, in our center, we favored using its various modifications. We were unable to obtain and evaluate late postoperative CT scans for 6 patients $(16.2 \%)$ who survived the aortic procedure. We also acknowledge that $67.5 \%$ of our

TABLE 5. Studies that evaluated the effectiveness of using interposition grafts for coronary reimplantation

\begin{tabular}{|c|c|c|c|c|c|c|c|c|}
\hline Source & $\begin{array}{c}\text { Total no. } \\
\text { of patients } \\
\text { in the study }\end{array}$ & $\begin{array}{l}\text { No. of } \\
\text { patients with } \\
\text { Cabrol } \\
\text { procedure } \\
\end{array}$ & $\begin{array}{c}\text { Cabrol } \\
\text { technique } \\
\text { type } \\
\end{array}$ & Mortal & lity, \% & $\begin{array}{l}\text { Survival } \\
\text { rate, } \%\end{array}$ & $\begin{array}{c}\text { Reported } \\
\text { complications related } \\
\text { to the Cabrol graft } \\
\end{array}$ & $\begin{array}{c}\text { Follow-up } \\
\text { contrast } \\
\text { angiography } \\
\text { or CT graft } \\
\text { assessment, } \\
(\% \text { of patients) } \\
\end{array}$ \\
\hline Cabrol et al, ${ }^{7} 1986$ & 100 & 100 & Classic & 4 & 12 & 75 at $8 y$ & None & Yes (29.8) \\
\hline Svensson et al, ${ }^{8} 1992$ & 348 & 157 & Classic & 8 & - & 76 at $3 y$ & Occlusion of RCA in 2 patients & No \\
\hline Lund et al, ${ }^{9} 1993$ & 17 & 17 & Classic & 41 & 0 & 100 at $30 \mathrm{mo}$ & $\begin{array}{l}\text { Occlusion of right limb of graft } \\
\text { in } 1 \text { patient }\end{array}$ & No \\
\hline Jault et al, ${ }^{22} 1994$ & 339 & 260 & Classic & $7.6^{*}$ & $22.4 *$ & 60 at $9 y^{*}$ & None & No \\
\hline Aoyagi et al, ${ }^{21} 1994$ & 66 & 20 & Classic & $10.6^{*}$ & $20.3 *$ & 71 at $10 y^{*}$ & None & Yes (100) \\
\hline Midulla et al, ${ }^{25} 1994$ & 140 & 15 & Classic & 20 & $10.5^{*}$ & 52 at $5 \mathrm{y}$ & None & No \\
\hline Bachet et al, ${ }^{10} 1996$ & 203 & 26 & Classic & $7.3^{*}$ & $18.4^{*}$ & 58 at $8 y$ & $\begin{array}{l}\text { Thrombosis of the graft in } \\
1 \text { patient }\end{array}$ & No \\
\hline 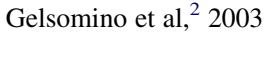 & 45 & 45 & Classic & 20 & 16.6 & 59 at $10 \mathrm{y}$ & $\begin{array}{l}\text { Occlusion of the graft limb to } \\
\text { LCA in } 1 \text { patient }\end{array}$ & No \\
\hline Hirasawa et al, ${ }^{16} 2006 \dagger$ & 71 & 71 & Modified & 4.2 & 1.4 & 94 at $5 y$ & None & No \\
\hline Garlicki et al, ${ }^{26} 2006$ & 25 & 25 & $\begin{array}{l}\text { Classic }(24 \%) \\
\text { and modified } \\
(76 \%)\end{array}$ & 0 & 8.0 & & None & Yes (100) \\
\hline Jault et al, ${ }^{27} 2006$ & 77 & 35 & Classic & $10.4^{*}$ & 35.1 & 42 at $12 y^{*}$ & Not reported & No \\
\hline Kitamura et al, ${ }^{23} 2011$ & 36 & 36 & Classic & 2.8 & 20.0 & 73 at $10 y$ & $\begin{array}{l}\text { Occlusion of the RCA ostium in } \\
\text { one patient; stenosis of the } \\
\text { RCA ostium in } 1 \text { patient }\end{array}$ & Yes (51) \\
\hline Maureira et al, ${ }^{17} 2012 \dagger$ & 153 & 153 & Modified & 8.5 & 16.8 & 74 at $10 y$ & $\begin{array}{l}\text { Anastomosis pseudoaneurysm } \\
\text { in } 1 \text { patient }\end{array}$ & Yes (78) \\
\hline Present study, 2013 & 40 & 40 & Modified & 7.5 & 16.2 & 73 at $6 y$ & None & Yes (84) \\
\hline
\end{tabular}


patients received mechanical valves that required them to receive life-long anticoagulant therapy, which could be a contributing factor to the favorable performance of the modified Cabrol grafts in the long-term.

\section{CONCLUSIONS}

Our study provides evidence that various modifications of the Cabrol procedure that involve using interposition grafts for coronary reimplantation are safe and durable. Although we do not recommend routine application of the modified Cabrol technique, we strongly suggest keeping it in mind as a good option for reinstating coronary flow during complex redo cases of aortic root pathology in which coronary buttons cannot be mobilized and brought to the main Dacron graft (especially because of postoperative scarring from a prior procedure). The modified Cabrol procedure is a valuable tool in the surgeon's armamentarium.

\section{References}

1. Hiratzka LF, Bakris GL, Beckman JA, Bersin RM, Carr VF, Casey DE Jr, et al. $2010 \mathrm{ACCF} / \mathrm{AHA} / \mathrm{AATS} / \mathrm{ACR} / \mathrm{ASA} / \mathrm{SCA} / \mathrm{SCAI} / \mathrm{SIR} / \mathrm{STS} / \mathrm{SVM}$ guidelines for the diagnosis and management of patients with thoracic aortic disease: a Report of the American College of Cardiology Foundation/American Heart Association Task Force on Practice Guidelines, American Association for Thoracic Surgery, American College of Radiology, American Stroke Association, Society of Cardiovascular Anesthesiologists, Society for Cardiovascular Angiography and Interventions, Society of Interventional Radiology, Society of Thoracic Surgeons, and Society for Vascular Medicine. J Am Coll Cardiol. 2010;55:e27-129.

2. Gelsomino S, Frassani R, Da Col P, Morocutti G, Masullo G, Spedicato L, et al. A long-term experience with the Cabrol root replacement technique for the management of ascending aortic aneurysms and dissections. Ann Thorac Surg. 2003;75:126-31.

3. Wheat MW Jr, Wilson JR, Bartley TD. Successful replacement of the entire ascending aorta and aortic valve. JAMA. 1964;188:717-9.

4. Bentall H, De Bono A. A technique for complete replacement of the ascending aorta. Thorax. 1968;23:338-9.

5. Cabrol C, Pavie A, Gandjbakhch I, Villemot JP, Guiraudon G, Laughlin L, et al. Complete replacement of the ascending aorta with reimplantation of the coronary arteries: new surgical approach. J Thorac Cardiovasc Surg. 1981;81: 309-15.

6. Kouchoukos NT, Wareing TH, Murphy SF, Perrillo JB. Sixteen-year experience with aortic root replacement: results of 172 operations. Ann Surg. 1991;214: 308-18; discussion 318-20.

7. Cabrol C, Pavie A, Mesnildrey P, Gandjbakhch I, Laughlin L, Bors V, et al. Longterm results with total replacement of the ascending aorta and reimplantation of the coronary arteries. J Thorac Cardiovasc Surg. 1986;91:17-25.

8. Svensson LG, Crawford ES, Hess KR, Coselli JS, Safi HJ. Composite valve graft replacement of the proximal aorta: comparison of techniques in 348 patients. Ann Thorac Surg. 1992;54:427-37; discussion 438-9.
9. Lund JT, Thiis JJ, Hjelms E. Composite graft replacement of the aortic valve and ascending aorta with Cabrol technique. Scand J Thorac Cardiovasc Surg. 1993; 27:99-103.

10. Bachet J, Termignon JL, Goudot B, Dreyfus G, Piquois A, Brodaty D, et al. Aortic root replacement with a composite graft: factors influencing immediate and long-term results. Eur J Cardiothorac Surg. 1996;10:207-13.

11. Patel D, Arteaga RB, Robinson VJ, Patel NA, Kapoor D. Angina, an unusual and late complication of the Cabrol procedure: a case report and review of the literature. Am J Med Sci. 2008;335:151-3.

12. Svensson LG, Crawford ES, Coselli JS, Safi HJ, Hess KR. Impact of cardiovascular operation on survival in the Marfan patient. Circulation. 1989;80:I233-42.

13. Kourliouros A, Soni M, Rasoli S, Grapsa J, Nihoyannopoulos P, O'Regan D, et al Evolution and current applications of the Cabrol procedure and its modifications. Ann Thorac Surg. 2011;91:1636-41.

14. Piehler JM, Pluth JR. Replacement of the ascending aorta and aortic valve with a composite graft in patients with nondisplaced coronary ostia. Ann Thorac Surg. 1982;33:406-9.

15. Mills NL, Morgenstern DA, Gaudiani VA, Ordoyne F. "Legs" technique for management of widely separated coronary arteries during ascending aortic repair. Ann Thorac Surg. 1996;61:869-74.

16. Hirasawa Y, Aomi S, Saito S, Kihara S, Tomioka H, Kurosawa H. Long-term results of modified Bentall procedure using flanged composite aortic prosthesis and separately interposed coronary graft technique. Interact Cardiovasc Thorac Surg. 2006;5:574-7.

17. Maureira P, Vanhuyse F, Martin C, Lekehal M, Carteaux JP, Tran N, et al. Modified Bentall procedure using two short grafts for coronary reimplantation: longterm results. Ann Thorac Surg. 2012;93:443-9.

18. Ayyash B, Tranquilli M, Elefteriades JA. Femoral artery cannulation for thoracic aortic surgery: safe under transesophageal echocardiographic control. J Thorac Cardiovasc Surg. 2011;142:1478-81.

19. Gega A, Rizzo JA, Johnson MH, Tranquilli M, Farkas EA, Elefteriades JA Straight deep hypothermic arrest: experience in 394 patients supports its effectiveness as a sole means of brain preservation. Ann Thorac Surg. 2007;84: 759-66; discussion 766-7.

20. Ziganshin B, Elefteriades JA. Does straight deep hypothermic circulatory arrest suffice for brain preservation in aortic surgery? Semin Thorac Cardiovasc Surg. 2010;22:291-301.

21. Aoyagi S, Kosuga K, Akashi H, Oryoji A, Oishi K. Aortic root replacement with a composite graft: results of 69 operations in 66 patients. Ann Thorac Surg. 1994; 58:1469-75.

22. Jault F, Nataf P, Rama A, Fontanel M, Vaissier E, Pavie A, et al. Chronic disease of the ascending aorta: surgical treatment and long-term results. $J$ Thorac Cardiovasc Surg. 1994;108:747-54.

23. Kitamura T, Kigawa I, Fukuda S, Miyairi T, Takamoto S. Long term results with the Cabrol aortic root replacement. Int Heart J. 2011;52:229-32.

24. Knight J, Baumuller S, Kurtcuoglu V, Turina M, Turina J, Schurr U, et al. Longterm follow-up, computed tomography, and computational fluid dynamics of the Cabrol procedure. J Thorac Cardiovasc Surg. 2010;139:1602-8.

25. Midulla PS, Ergin A, Galla J, Lansman SL, Sadeghi AM, Levy M, et al. Three faces of the Bentall procedure. J Card Surg. 1994;9:466-81.

26. Garlicki M, Roguski K, Puchniewicz M, Ehrlich MP. Composite aortic root replacement using the classic or modified Cabrol coronary artery implantation technique. Scand Cardiovasc J. 2006;40:230-3.

27. Jault F, Rama A, Lievre L, Bonnet N, Leprince P, Pavie A, et al. Chronic dissection of the ascending aorta: surgical results during a 20 -year period (previous surgery excluded). Eur J Cardiothorac Surg. 2006;29:1041-5. 